\title{
Kerencatan Hubungan Diplomatik Kesultanan Melayu Melaka, Johor dan Aceh \\ The Deterrence of Malay Government Diplomatic Relationship with Malacca, Johore and Aceh
}

\section{SALMAH JAN NOOR MUHAMMAD}

\author{
Jabatan Bahasa Melayu, Fakulti Bahasa Moden dan Komunikasi, 43400 Universiti Putra Malaysia \\ Serdang, Selangor
}

Salmahjan@upm.edu.my

\begin{abstract}
Abstrak Hubungan diplomatik merupakan hubungan yang terjalin di antara dua atau lebih kerajaan. Pada dasarnya, hubungan ini terbina atas dasar kepercayaan, keserasian dan keinginan untuk menjayakan matlamat yang sama demi kepentingan kerajaan masing-masing. Namun, hubungan diplomatik ini akan mengalami kerencatan apabila segelintir pemerintah kerajaan tidak lagi terikat dengan nilai integriti dan melihat 'kuasa' sebagai agenda utama dalam hubungan tersebut. Makalah ini bertujuan mengkaji faktor penyebab berlakunya permasalahan ini. Bagi memperoleh data, penulis melakukan kajian kepustakaan. Hasil dapatan menemui bahawa faktor kerencatan ini berlaku disebabkan oleh interaksi sosial yang berbeza antara kerajaan, matlamat untuk menjadi 'kerajaan autokratik' dan akibat perlanggaran prinsip etika dan moral hidup. Naskhah Sulalatus Salatin, Tuhfat al-Nafis dan Hikayat Aceh akan dijadikan sebagai bahan perbincangan utama.
\end{abstract}

Kata kunci: Kerencatan, diplomatik, pemerintah, integriti, autokratik, interaksi sosial.

Abstract Diplomatic relationship is an affliation that is formed between two or more governments. Essentially, this relationship is built on belief, compatibility and desire to achieve similar goals for the sake of their respective state interests. However, this diplomatic relationship will decline when government rulers are bound with the value of integrity and perceive 'power' as main agenda in that affiliation. This article aims to study the causal factor towards this problem. To obtain data, the author prepared a 
precise literature study. Results of the study showed that factors that lead to this interference are social interaction that is diverse between governments, the goal of becoming the 'autocratic government, 'and the collision of the principle of ethics and moral life. The copy of Sulalatus Salatin, Tuhfat alNafis and Hikayat Aceh will be utilised as the main discussion materials.

Keywords: Deterrent, diplomatic, government, integrity, autocratic, social interaction.

\section{PENGENALAN}

Hubungan diplomatik merupakan hubungan yang terjalin di antara kerajaan atas dasar permuafakatan. Menurut Mokhtar Muhammad (2005:18), diplomatik ialah hubungan tersusun antara kerajaan dan merupakan rangka asas kepada perhubungan antara negara dengan menggunakan kebijaksanaan dan budi bicara dalam perhubungan rasmi di antara negara. Sesebuah hubungan diplomatik yang tersusun akan memudahkan jalinan hubungan kerjasama yang erat antara sesebuah kerajaan, sama ada dari sudut hubungan sosial, budaya, agama, ekonomi mahupun politik. Sementara itu, Holsti (1983: 19) pula menyatakan bahawa diplomatik merujuk kepada semua bentuk interaksi antara anggota pelbagai masyarakat (negara) sama ada disokong oleh kerajaan ataupun tidak.

Terdapat pelbagai takrifan mengenai pengertian diplomatik. Dalam Ensiklopedia Dunia(2005: 216), istilah diplomatik ditakrifkan sebagai kaedah pengendalian perundingan antara negara yang melibatkan pembentukan dasar yang diikuti oleh sesebuah negara untuk mempengaruhi negara lain. Joshua S. Goldstein (1994: 1) berpendapat bahawa diplomatik merujuk kepada kajian mengenai hubungan antara kerajaan. Beliau turut menekankan bahawa hubungan tersebut dipengaruhi oleh faktor geografi dan sejarah, sementara diplomatik dalam perspektif Islam bermaksud;

The aims of the Prophet's diplomacy, or his principle of international relations, was based on the concept of a just and fair world order, in which all states, strong or weak, big or small, should enjoy peace, 
stability, freedom of conscience and human welfare. In the conduct of foreign relations, the Prophet was always guided by the noble moral principles laid down in the Quran.

(Choudhury, G. W, 1993a: 99)

Berdasarkan kepada definisi diplomatik yang telah dibincangkan jelas diplomatik merupakan hubungan yang terjalin antara dua atau lebih kerajaan yang mempunyai matlamat dan kepentingan bersama. Apabila misi dan visi kerajaan-kerajaan tersebut selari, maka hubungan diplomatik mudah terjalin. Dalam hal ini, hubungan diplomatik itu bukan sahaja memenuhi kelompangan atau kepentingan bersama semata, malah sesebuah kerajaan itu perlu bertindak dengan menumpukan kepada kaedah pembentukan, penyusunan serta mengawal jalinan hubungan diplomatik dengan teliti agar hubungan tersebut tidak mudah terganggu dengan ancaman luar. Dengan kata lain, situasi ini akan membawa kepada perancangan yang sistematik dan mantap dalam pengendalian hubungan diplomatik.

Hubungan diplomatik sebenarnya sudah wujud di alam Nusantara, terutamanya pada zaman pra-Islam lagi. Hall, D.G.E (1966: 25) menyatakan bahawa Empayar Funan merupakan antara kerajaan Melayu terbesar dan tertua di Semenanjung Indochina yang telah mengamalkan hubungan diplomatik. Pernyataan tersebut turut dipersetujui oleh Mohd Jamil Mukmin (2011: 71). Beliau berpendapat bahawa kerajaan Melayu seperti Funan, Campa, Langkasuka dan Kedah Tua telah menjalinkan hubungan diplomatik dengan beberapa kerajaan besar seperti China, Arab dan India. Faktor utama hubungan tersebut terjalin ialah untuk memperkembangkan lagi aktiviti perdagangan, mengukuhkan agama Hindu-Buddha dan meluaskan pengaruh politik. Kesannya, kerajaan Melayu tersebut merupakan antara kerajaan Melayu yang kukuh dari segi pemerintahan dan pentadbiran kerajaan.

Kedatangan Islam ke Nusantara telah berjaya membentuk sebuah hubungan diplomatik yang lebih sistematik. Di Nusantara, Islam mula bertapak dianggarkan pada tahun 225 Hijrah bersamaan dengan $840 \mathrm{M}$ di Perlak (Hashim Musa, 2004: 40). Islam telah membawa perubahan besar dalam seluruh kehidupan masyarakat Melayu, terutamanya dalam hubungan diplomatik sehingga membentuk suatu tamadun bangsa yang kekal sehingga 
hari ini. Dalam agama Islam telah menegaskan tentang prinsip hubungan diplomatik itu perlu berdasarkan prinsip persaudaraan, persahabatan dan perdamaian. Prinsip hubungan diplomatik menurut hukum Islam antara lain ialah menghargai manusia sebagai makhluk yang terbaik, menegakkan keadilan, persamaan, kemerdekaan, menepati janji, toleransi, mencegah kejahatan, dan bukannya mewujudkan peperangan dan permusuhan (H.A.Fuad Said, 2002: 409). Sementara itu, 'AbdulHamīd A. AbūSulaymān (1987) juga mengatakan bahawa prinsip asas sesebuah hubungan diplomatik itu seharusnya berlandaskan tauhid, berpegang kepada keadilan, keamanan, sokongan dan kerjasama, jihad, menghormati serta memenuhi iltizam. Sebahagian prinsip ini menjadi amalan kepada kerajaan Islam di Tanah Melayu seperti Kerajaan Melaka, Aceh, Johor Riau dan juga Aceh dalam menjalinkan hubungan diplomatiknya.

Keadaan ini menjadi lancar apabila sesebuah kerajaan itu menerapkan Islam sebagai suatu cara hidup berpolitik (Muhammad Afifi Abdul Razak \& Azman Md Zain, 2003: 46). Sebagai sebuah agama yang bersifat sejagat, Islam menyeru ke arah pengwujudan suatu bentuk hubungan antara manusia, bangsa dan negara merentasi sempadan nasional atau hubungan antarabangsa. Contohnya, Kerajaan Melaka yang telah membentuk hubungan merentas sempadan menerusi perkahwinan. Perkahwinan antara Kerajaan Melaka (Sultan Mansur) dengan Kerajaan Majapahit (Raden Galoh Cendera Kirana) dan Kerajaan China (Puteri Hang Liu) telah memberikan kesan positif kepada Kerajaan Melaka dalam bidang politik, ekonomi dan juga sosial. Dalam bidang politik, misalnya dengan mendapat perlindungan daripada Kerajaan Majapahit dan China, Melaka telah berjaya menangani ancaman dari anasir luar seperti Siam yang ingin mengganggu gugat keselamatan Melaka. Situasi ini telah memakmurkan Melaka dan impaknya, ekonomi dan sosial Kerajaan Melaka turut berkembang pesat apabila ramai pedagang daripada negara luar seperti Kaherah, Mekah, Orissa, Ceylon, Malindi, Ormuz, Parsi, Turki, Maluku, Jawa, Timur, Maldive, Madura, Sunda dan Benggala (A.Samad Ahmad, 2010: 79 - 80). Keadaan tersebut turut dirakamkan oleh Tome Pires pada tahun 1512 dalam Suma Oriental of Tome Pires (Cartesao, A. (ed.), 1944: 287). Beliau menyatakan bahawa "Barang siapa menguasai Melaka, maka ia akan dapat menguasai Venice". Venice pada masa itu merupakan sebuah pelabuhan yang besar di Eropah bagi barang dagangan dari Asia. 
Selain itu, kesan daripada perhubungan Melaka dan China juga telah mewujudkan satu komuniti baharu di Melaka, iaitu komuniti Baba dan Nyonya. De Eredia melaporkan pada tahun 1613 orang Cina mula menetap di Melaka dan membentuk komuniti tersendiri pada awal kurun ke17. Disebabkan tiada pendatang wanita China pada waktu itu, maka lelaki Cina telah berkahwin dengan wanita Melayu tempatan. Oleh itu, mereka terpaksa menggunakan bahasa Melayu, bukan sahaja semasa berjual beli tetapi juga semasa berinteraksi dengan masyarakat tempatan dan dalam kalangan keluarga sendiri. Dengan demikian, satu proses pembudayaan Melayu telah berlaku ke atas mereka yang melahirkan satu budaya kacukan China-Melayu yang unik yang dinamakan sebagai Baba dan Nyonya (Hashim Musa, 2004: 147).

Sementara itu, hubungan Kerajaan Aceh pada zaman pemerintahan Sultan Iskandar Muda Johan Pahlawan Mahkota Alam (1590 - 1636) dengan Kerajaan Uthmaniyah juga telah membantu Kerajaan Aceh mengukuhkan sistem ketahanan dan pertahanan. Kaedah diplomatik yang digunakan oleh Sultan Aceh itu sangat menarik apabila baginda mengaplikasikan sistem barter dalam hubungan ini, iaitu dengan menghadiahkan rempah-ratus kepada pemerintah Uthmaniyah. Sementara itu, Khalifah Turki Uthmaniyah telah mengirim hadiah balasan berupa sebuah meriam dan penasihat militer untuk membantu memperkuatkan angkatan perang Kerajaan Aceh (Fadhullah Jamil, 1984: 40). Begitu juga yang berlaku dengan hubungan Kedah dan Siam. Hubungan diplomatik antara kedua buah kerajaan ini telah berubah coraknya semasa pemerintahan Sultan Ahmad Tajuddin Mukarram Syah (1854 - 1879). Hubungan dingin sebelum ini bertukar erat, setelah Sultan Ahmad Tajuddin mengahwini anak angkat Perdana Menteri Thai Chao Phraya, Sri Suriyawong (Samdet Chao Phraya) yang bernama Wan Jah binti Luang NikAbidin pada tahun 1955. Perkahwinan politik ini membawa kesan yang positif kepada baginda dalam hubungan Kedah dan Siam.

Tidak dinafikan, bentuk-bentuk hubungan yang terjalin atas faktor ekonomi, perkahwinan, politik dan juga agama ini sememangnya membawa kebaikan kepada kerajaan yang terlibat, sama ada kerajaan tersebut baharu sahaja dibuka mahupun kerajaan yang sudah mantap pembinaannya. Menurut Mohd Jamil Mukmin (2011: 71), lazimnya tujuan utama sesebuah 
kerajaan menjalinkan hubungan diplomatik dengan beberapa kerajaan besar adalah untuk mengelakkan ancaman musuh yang mengganggu urusan pemerintahan dan pentadbiran kerajaan berkenaan. Setiap kerajaan sama ada dalam zaman pra-Islam mahupun zaman Islam sangat mementingkan hubungan diplomatik untuk memantapkan pemerintahan dan pentadbiran. Dalam hal ini, kerjasama dan usaha sama dalam sesuatu dasar, konsep atau objektif yang ingin dicapai secara bersama merupakan perkara yang penting untuk ditekankan dan menjadi pendorong kepada sesebuah kerajaan itu mengadakan hubungan diplomatik.

Namun demikian, implikasi positif tentang hubungan diplomatik ini akan punah sekiranya kerajaan-kerajaan yang terlibat dengan perjanjian diplomatik ini berpaling tadah atau kerajaan yang baharu mewujudkan hubungan tersebut mempunyai niat di sebaliknya. Peperangan, pergaduhan, pembunuhan dan pengkhianatan pasti akan terjadi. Lebih menyedihkan, apabila kuasa sultan yang selayaknya memerintah dirampas kuasanya secara paksaan. Oleh itu, penulisan ini akan mengemukakan beberapa faktor yang menyebabkan kerencatan hubungan diplomatik, dengan memilih kerajaan Melaka, Johor dan Aceh sebagai contoh kerajaan yang mengalami proses berkenaan. Oleh itu, naskhah Sulalat al-Salatin, Tuhfat al-Nafis dan Hikayat Aceh akan digunakan sebagai bahan perbincangan utama.

\section{FAKTOR KERENCATAN HUBUNGAN DIPLOMATIK KESULTANAN MELAYU}

Dalam konteks tulisan ini, kerencatan dapat didefinisikan sebagai suatu tindakan yang membantutkan atau menggendalakan usaha untuk membentuk dan menjalinkan sesebuah hubungan diplomatik (Salmah Jan Noor Muhammad, 2013: 468). Menurut Chamil Wariya (1989: 149), berlakunya kerencatan kepada sesuatu hubungan itu disebabkan dua buah atau lebih negara telah mengambil pendirian yang bertentangan. Selain itu, ia berlaku kerana kedua-dua buah negara terlibat mengejar objektif bercanggah menerusi isu tertentu. Oleh hal yang demikian, pendirian dan objektif yang berlawanan inilah yang menyebabkan hubungan antara kedua-dua belah pihak menjadi tegang sehingga mencetuskan peperangan sekiranya tidak dikawal. 
Naskhah Melayu yang bergenre historiografi telah menceritakan tentang kerencatan hubungan diplomatik ini. Antaranya, Sulalat alSalatin, Tuhfat al-Nafis dan Hikayat Aceh. Naskhah ini merupakan antara naskhah yang diiktiraf sebagai karya agung Melayu dan mewakili beberapa kerajaan terkenal iaitu Melaka, Johor dan Aceh. Melalui penelitian terhadap naskhah di atas, telah dikenal pasti beberapa faktor yang menyumbang kepada berlakunya kerencatan hubungan sama ada semasa melangsungkan atau selepas menjalinkan hubungan diplomatik. Antaranya interaksi sosial berbeza antara kerajaan, matlamat untuk menjadi 'kerajaan autokratik' dan perlanggaran prinsip etika dan moral hidup.

\section{Interaksi Sosial yang Berbeza antara Kerajaan}

Interaksi sosial menurut Alo Liliweri (2005: 127) ialah suatu proses yang dilakukan oleh setiap orang ketika hendak bertindak dalam sebuah hubungan dengan orang lain. Sementara itu, Tim Mitra Guru (2006: 35) berpendapat bahawa interaksi sosial merupakan hubungan sosial yang dinamik yang mempunyai kaitan antara orang perseorangan, antara kelompok manusia, mahupun antara perseorangan dan kelompok manusia. Tambah mereka lagi, interaksi sosial boleh terjadi antara masyarakat walaupun mereka saling tidak mengenali. Hal ini demikian kerana masyarakat tersebut menyedari keperluan masing-masing dan mula bertindak dengan bertegur sapa, berjabat mesra serta berkenal-kenalan antara satu sama lain. Selain itu, Maryati dan Suryawati (2003: 22) menyatakan bahawa interaksi sosial ialah kontak atau hubungan timbal balik dan respons antara individu, antara kelompok atau antara individu dan kelompok. Pendapat lain yang dikemukakan oleh Murdiyatmoko dan Handayani (2004: 50) pula menyatakan interaksi sosial ialah hubungan antara manusia yang menghasilkan suatu proses pengaruh mempengaruhi yang menghasilkan hubungan tetap dan pada akhirnya memungkinkan pembentukan struktur sosial.

Interaksi sosial juga mampu mempengaruhi tindakan atau pemikiran seseorang, iaitu daripada pengaruh yang positif kepada negatif dan begitu juga sebaliknya. Interaksi positif akan menciptakan keselarasan pendapat dan tingkah laku seperti saling menghormati, menghargai, bekerjasama dan bantu-membantu dalam menangani masalah yang timbul antara masyarakat 
dalam sesebuah kerajaan. Interaksi jenis ini juga dapat mewujudkan hubungan timbal balik antara sebuah kerajaan dengan kerajaan lain. Interaksi negatif pula akan cenderung membentuk gejala negatif seperti permusuhan, pengkhianatan, rasa curiga dan menipu antara satu sama lain. Apabila perkara sedemikian berlaku, maka akan mendorong kepada berlakunya kerencatan kepada sesebuah hubungan.

Kegagalan memahami interaksi sosial antara kerajaan dalam konteks ini ialah kegagalan atau ketidakupayaan sesebuah kumpulan atau negara memahami tindakan atau tingkah laku dan pemikiran pemimpin negara lain daripada pelbagai sudut yang merangkumi sudut adat dan budaya, politik, ekonomi, serta agama. Sesebuah negara itu tidak dapat menerima atau memahami sesuatu perbezaan yang wujud dengan negara lain. Dalam hal ini, faktor penyebab kegagalan memahami interaksi sosial antara kerajaan lebih menjurus kepada perbezaan sosiobudaya seperti perbezaan dari segi tatacara penyempurnaan adat istiadat dan kegagalan mengadaptasikan budaya kerajaan lain.

Perbezaan dari segi tatacara penyempurnaan adat istiadat dapat ditemui dalam naskhah Sulalat al-Salatin apabila Maharaja Diraja dari Kerajaan Haru telah melantik Raja Pahlawan sebagai utusan kerajaan baginda untuk menjalinkan hubungan diplomatik dengan Kerajaan Pasai. Kerajaan Haru pada waktu itu merupakan antara kerajaan terkenal dan berpengaruh di Nusantara. Pendapat Tomes Pires yang tercatat dalam buku The Suma Oriental of Tomé Pires, hasil tulisan Cartesao, A. (1944) menyatakan bahawa Kerajaan Haru merupakan kerajaan yang dikenali sebagai Penguasa Terbesar di Sumatera yang memiliki wilayah kekuasaan yang luas dan memiliki pelabuhan yang ramai dikunjungi oleh kapal asing. Dalam laporannya, Tomes Pires juga mendeskripsikan akan kehebatan armada kapal laut Kerajaan Haru yang mampu melakukan pengawalan lalu lintas kapal dagang yang melalui Selat Melaka. Sementara itu, Kerajaan Pasai ialah sebuah kerajaan maritim. Ekonomi kerajaannya banyak bergantung kepada aspek perniagaan dan pelayaran. Lokasinya yang strategik sebagai pintu gerbang lalu lintas perdagangan antara India dan China menjadikan Pasai sebagai kerajaan dagang yang maju. Pasai juga 
merupakan pengeksport lada sebagai komoditi utama selain komoditi lain seperti sutera, kapur barus dan emas (Deni Prasetyo, 2009: 42).

Berdasarkan kelebihan yang ada pada kerajaan masing-masing, maka Kerajaan Haru mula mengorak langkah dan menyedari bahawa ikatan kerjasama dengan Kerajaan Pasai akan membantu kerajaan masing-masing memperkukuhkan serta memperkuatkan aspek pertahanan. Memandangkan kedua-dua buah kerajaan terlibat dengan perdagangan yang menggunakan jalan laut, maka ancaman lanun tidak mustahil berlaku. Oleh itu, kerjasama antara kedua-dua kerajaan akan dapat melengkapi kekurangan yang wujud. Justeru, Maharaja Diraja telah menghantar Raja Pahlawan sebagai utusan Kerajaan Haru bagi menyampaikan hajat murni baginda untuk menjalinkan hubungan diplomatik dengan Kerajaan Pasai (A. Samad Ahmad, 2010: 176). Namun, hasrat tersebut tidak tercapai apabila Raja Pahlawan telah melakukan onar semasa majlis 'sambutan utusan' Raja Pasai diadakan. Peristiwa tersebut terjadi disebabkan terdapatnya perbezaan protokol atau tatacara pembacaan warkah antara Kerajaan Haru dan Pasai. Dalam peristiwa ini, khatib Pasai telah membaca 'salam' kepada 'sembah.'

Adapun di dalam surat itu, "Salam paduka kakanda." Maka oleh khatib itu, "Paduka kakanda empunya sembah, datang kepada paduka adinda." Maka kata Raja Pahlawan, "Lain surat lain dibaca; salam dikata sembah." Maka oleh khatib itu dibacanya "sembah" juga. Maka berkata pula Raja Pahlawan, "Ah, lain surat, lain dibaca; remak mati di tanah Pasai, jangan mati di tanah Haru. Jika demikian anjing Pasai pun tahu akan sebuah sepatah.” Maka dibaca juga oleh khatib Pasai itu "sembah".

(A. Samad Ahmad, 2010: 176)

Perbezaan adat istiadat, khususnya semasa pembacaan warkah itu telah menimbulkan kemarahan kepada Raja Pahlawan. Walaupun beberapa kali ditegur oleh beliau, khatib Pasai tetap membaca perkara yang sama. Dalam situasi ini, Raja Pahlawan tidak memahami secara keseluruhan adat istiadat Kerajaan Pasai dan kurang persediaan dalam menghadapi situasi tersebut. Pada masa yang sama, beliau juga ingin mempertahankan kedaulatan Kerajaan Haru daripada menjadi kerajaan di bawah naungan Pasai. Dalam hal ini, jelas menggambarkan bahawa nilai toleransi dan dasar persefahaman tidak lagi menjadi kepentingan kepada kedua-dua 
pihak. Situasi paling penting pada saat itu ialah memenangkan pendirian masing-masing. Kesannya, telah berlaku pembunuhan tidak terancang di bumi Pasai. Raja Pahlawan telah mengamuk di balai istiadat Kerajaan Pasai dan mengakibatkan ramai yang terbunuh. Bagaimanapun, pihak Pasai tidak berdiam diri melihat kelakuan Raja Pahlawan itu. Mereka turut sama bertindak dan membunuh Raja Pahlawan serta pengikutnya.

Maka Raja Pahlawan pun terlalu marah; maka diamuknya segala orang di balai itu, banyak matinya. Maka orang pun gemparlah, maka oleh orang Pasai, Raja Pahlawan dibunuhnya, dan segala temannya itu habis dibunuhnya. Maka barang orang Haru yang tinggal itu kembalilah ke Haru, memberitahu rajanya. Maka Maharaja Diraja pun terlalu marah, maka disuruhnya serang Pasai; sebab itulah, maka Haru berkelahi dengan Pasai.

\section{(A. Samad Ahmad, 2010: 176 )}

Bak kata pepatah 'mengikut rasa hati akan binasa' Raja Pahlawan selaku utusan diraja tidak memainkan peranannya sebagai seorang utusan diraja dalam hal ini. Ciri seorang utusan seperti mahir berkomunikasi dan bijak membaca serta menyesuaikan 'bahasa badan' (body language) gagal ditonjolkan oleh Raja Pahlawan. Seharusnya, beliau bijak mengawal dan lebih tenang menghadapi situasi tersebut. Selain itu, Raja Pahlawan juga perlu menggunakan teknik atau pendekatan bersesuaian berdasarkan situasi yang tegang itu untuk mengelakkan masalah tersebut daripada berlaku. Misalnya, pendekatan interaksi yang mampu memenangi hati seseorang atau sesebuah kumpulan dan dapat meningkatkan kefahaman dan kemesraan serta tidak menyakitkan hati orang yang lawan bercakap (Arshad Md. Gaus, 2005: 20). Dengan adanya pendekatan seperti ini, kedua-dua kerajaan akan lebih memahami permasalahan yang berlaku dan seterusnya dapat memperkukuhkan semangat persaudaraan, kerjasama dan dapat menjalinkan hubungan yang baik.

Selain itu, kegagalan interaksi sosial juga dapat dilihat daripada perspektif mengadaptasikan budaya sesebuah kerajaan. Dalam masyarakat Melayu, salah satu budaya yang penting ialah budaya sopan santun. Budaya sopan santun dalam kalangan masyarakat Melayu merupakan budaya yang 
diwarisi daripada ajaran dan asuhan nenek moyang. Ia menjadi amalan dan cara hidup yang melambangkan identiti bermasyarakat dan mencerminkan kemuliaan akhlak serta tingkah laku seseorang. Budi bahasa dan budi bicara merupakan antara elemen penting yang terdapat dalam budaya sopan santun. Menurut Hashim Musa (2001: 80), budi bahasa dan budi bicara merujuk kepada pertuturan yang manis, sopan, positif, bijaksana, bernas dan penuh pengajaran serta sumbangan kepada khalayak dan pendengarnya.

Sehubungan itu, masyarakat Melayu sangat menekankan aspek budaya sopan santun dalam kehidupan. Kegagalan mengaplikasikannya akan membawa pandangan serong kepada keperibadian seseorang, sama ada seseorang itu berbangsa Melayu atau sebaliknya. Namun, dalam keterikatan berpegang kepada budaya Melayu, sebenarnya masyarakat Melayu merupakan masyarakat yang terbuka dan bertolak ansur. Hal ini terbukti melalui peristiwa kedatangan bangsa asing ke Tanah Melayu. Dalam naskhah Sulalat al-Salatin, diceritakan oleh pengarang naskhah bahawa pengikut Bendahara Seri Maharaja ingin memarahi kapitan kapal Peringgi yang memakaikan sendiri rantai emas berpermata ke leher Bendahara Seri Maharaja. Namun, ditegah oleh Bendahara lalu berkat, "Jangan kamu turuti, kerana ia orang yang tiada tahu bahasa" (A. Samad Ahmad, 2010: 245).

Walaupun masyarakat Melayu sangat bertoleransi dalam aspek budaya, dalam masa yang sama mereka sangat mengharapkan pengertian dalam kalangan orang asing ini untuk belajar menghormati dan secara perlahan-lahan mengadaptasikan budaya tersebut. Hal ini demikian kerana kegagalan mengadaptasikan budaya boleh membawa kepada kerencatan hubungan diplomatik, misalnya peristiwa yang terdapat dalam naskhah Tuhfat al-Nafis yang mengisahkan tentang hal ini (kegagalan mengadaptasikan budaya).

Setelah pihak Belanda dan Melayu mengikat perjanjian untuk hidup berdamai (Hooker, Virginia Matheson, 1998: 266 \& 270), Sultan Mahmud bersetuju untuk meletakkan seorang wakil kompeni Belanda dalam Kerajaan Riau yang bernama Abran Rudi dengan niat untuk merapatkan lagi hubungan diplomatik, selain mendapat sokongan sumber ekonomi dan politik daripada Kerajaan Belanda. Sudah menjadi adat Melayu, tetamu yang datang akan 
dilayan dengan baik, tetapi situasi tersebut tidak berlaku pada pihak Belanda. Wakil yang dihantar tersebut telah melakukan perbuatan dan menuturkan perkataan yang tidak sopan sehingga menyinggung perasaan Sultan Mahmud dan pembesar lain. Hal ini sangat mengecewakan Sultan Mahmud kerana Abran Rudi telah memperlakukan baginda dan pembesarnya seperti hamba. Sebagaimana yang tergambar dalam petikan:

\begin{abstract}
Syahadan kata setengah riwayat orang tua-tua yang sampai kepada aku, adalah wakil kompeni di dalam Riau itu, iaitu namanya Abran Rudi, adalah terkeras sedikit perintahnya atas orang-orang Melayu, dan selalu juga bersalah-salahan faham dengan Raja Indera Bongsu. Dan apabila ia berkehendakkan kayu-kayan pada membaikkan rumah tangga dan kotanya, maka pergilah ia sendiri kepada Sultan Mahmud dipintanya apa-apa kehendaknya itu dengan perkataan yang kasar-kasar tiadalah ia hirau amat akan orang besar-besar di dalam negeri Riau itu. Apa-apa yang maksudkannya pergilah ia sendiri atau menyuruh orang-orangnya. Apabila terlambat sedikit dapatnya maksud itu maka marahlah ia. Di dalam hal itu jadi kesusahanlah atas Baginda Sultan Mahmud itu serta segala orang tua-tua yang di dalam negeri Riau itu, mungkin sehari mangkin bertambah keras perintahnya wakil kompeni itu. Maka jadilah selalu juga bersalahsalahan faham dan maksudnya maka dengan Raja Indera Bongsu itu demikianlah halnya sehari-hari konon adanya.
\end{abstract}

(Hooker, Virginia Matheson, 1998: 268)

Tidak padan dengan kelakuannya sebagai seorang tetamu, Abran Rudi berlagak seperti beliaulah pemerintah di Riau. Setiap kemahuannya perlu dituruti dan jauh sama sekali untuk menghormati dan mempelajari serta mengadaptasikan budaya masyarakat Melayu yang terkenal dengan budaya sopan santun ke dalam dirinya. Sebenarnya, dalam hal ini, tidak salah untuk Abran Rudi mengadaptasikan budaya Melayu sebagai tanda menghormati perhubungan diplomatik antara dua kerajaan, apatah lagi beliau tinggal di kawasan yang majoritinya Melayu. Namun, disebabkan keangkuhan dan kesombongannya, beliau enggan berbuat demikian. Pada waktu itu, penjajah seperti British, Belanda dan Amerika Syarikat terkenal dengan slogan 'Beban Orang Putih,' iaitu dasar tanggungjawab dan memimpin serta membawa orang-orang Timur ke arah kehidupan lebih sejahtera (Akashah Ismail, 2010: 229). Oleh itu, setiap tindakan yang dilakukan oleh mereka 
merupakan perkara yang paling sempurna. Akhirnya, hubungan kedua-dua kerajaan terjejas dan orang Melayu dan Bugis yang berada di negeri lain seperti Selangor dan Pahang telah menyerang Belanda yang berada di Riau dan Melaka kerana kebiadaban orang Belanda terhadap Sultan Mahmud dan pembesar baginda.

\section{Matlamat untuk Menjadi 'Kerajaan Autokratik'}

'Kerajaan autokratik' merupakan pemerintahan dan pentadbiran serta pengurusan yang berkuasa mutlak yang diamalkan oleh sesebuah kerajaan. Dengan kata lain, pemimpin negara tersebut ingin menjadikan kerajaannya sebagai kuasa pusat kepada kerajaan lain. Oleh hal yang demikian, manamana kerajaan yang tidak mematuhi arahan dianggap mencabar kuasanya. Menurut Abdullah Hassan dan Ainon Mohd (2007: 61), kerajaan yang mengamalkan pentadbiran autokratik akan menentukan cara bagaimana setiap kerja dan aktiviti dalam sesebuah kerajaan itu dilakukan. Kerajaan yang berada di bawah kawalan kerajaan autokratik tidak mempunyai kebebasan untuk bersuara dan hal ini telah menyebabkan kerencatan hubungan diplomatik antara kerajaan.

Antara strategi yang digunakan oleh 'kerajaan autokratik' ialah mengamalkan dasar naungan secara paksaan. Dasar naungan secara paksaan ini bukan sahaja mampu mengukuh dan menebarkan kuasa dan seterusnya memonopoli aspek politik kerajaan lain, malahan rakyat negeri naungan akan bertukar paksi pemerintah, iaitu dengan mencurahkan taat setia kepada kerajaan autokratik. Kerajaan autokratik ini melancarkan dasar pengawalan minda dan fizikal secara paksaan bagi meneruskan kuasa secara mutlak di bawah naungannya. Maka, pemerintah sedia ada di negeri berkenaan akan dijadikan 'boneka' dan paling malang, apabila terdapat pemerintah kerajaan tersebut menjadi tawanan dan mangsa pembunuhan.

Secara jujurnya, dasar ini banyak memberi kesan negatif seperti peperangan, pembunuhan, pemberian ufti secara paksa, wujudnya komplot dan berlakunya pemberontakan. Perkara sedemikian timbul disebabkan pemerintah, pembesar dan rakyat yang dinaungi secara paksaan itu bergabung tenaga dan akal fikiran untuk mendapatkan kembali kedaulatan 
dan maruah kerajaan mereka. Dengan usaha tersebut, ia bukan sahaja menimbulkan banyak bencana kepada kedua-dua kerajaan, malahan jalan untuk menuju ke arah kecapaian hubungan diplomatik kelihatan buntu.

Dalam naskhah Tuhfat al-Nafis, Raja Kecik, iaitu Raja Siak dan selaku Sultan Johor dan Riau (raja sementara) telah memaksa Pahang menjadi salah satu kerajaan di bawah naungan baginda. Tujuannya, untuk menambahkan koleksi 'kerajaan taklukan' dan seterusnya menjadikan Siak sebagai kerajaan autokratik di Tanah Melayu. Pada ketika itu, Kerajaan Pahang diperintah oleh Sultan Abd al-Jalil. Sultan Abd al-Jalil merupakan bekas Sultan Johor yang turun takhta disebabkan terdapat dakwaan bahawa baginda bukanlah waris sebenar keturunan Johor. Raja Kecik dengan bantuan menteri baginda telah berjaya mempengaruhi minda rakyat negeri Johor untuk mengesahkan bahawa baginda ialah putera kepada Marhum Mangkat Dijulang (Sultan Mahmud) (Hooker, Virginia Matheson, 1998: 46, 48 \& 56).

Berbalik kepada peristiwa bermulanya Johor-Riau-Siak menjadi negeri naungan kepada Pahang, Raja Kecik telah mendapat perkhabaran bahawa Sultan Abd al-Jalil telah membuka negeri Pahang. Raja Kecik merasa tidak gembira dengan perkhabaran tersebut. Hal ini ada kaitannya dengan peristiwa Raja Siak telah merampas takhta Kerajaan Johor dan Riau daripada Sultan Abd al-Jalil. Justeru, pembukaan negeri baharu oleh Sultan Abd al-Jalil dibimbangi oleh Raja Kecik untuk mengambil semula Johor dan Riau, dan mendapatkan semula pengaruh daripada kawasan sekitar untuk memerangi Johor. Oleh itu, Raja Kecik telah memberi kata dua kepada Sultan Abd al-Jalil untuk tunduk kepada kekuasaan baginda dan mengaku kedaulatan Raja Kecik serta bersedia untuk dinaungi oleh kerajaan baginda. Sekiranya Sultan Abd al-Jalil menolak tawaran baginda itu, maka baginda akan menyerang negeri Pahang.

Dalam hal ini, Sultan Abd al-Jalil merasa tercabar dan tidak ingin pisang berbuah dua kali. Johor dan Riau sudah diberikannya dan kini, Pahang perlu dipertahankan demi maruah dan martabat waris keturunannya. Keegoan Raja Kecik untuk menjadi kerajaan autokratik perlu dibanteras. Baginda sedia untuk berperang dengan angkatan Raja Kecik yang diketuai oleh Laksamana Nakhoda Sekam. Namun apatah daya, nasib tidak 
menyebelahi Sultan Abd al-Jalil. Dalam peperangan tersebut, baginda telah dikalahkan oleh angkatan tentera Raja Kecik dan telah menjadi tawanan sebelum dibunuh semasa dalam pelayaran menuju ke Riau.

... Maka pergilah segala angkatan itu kepalanya Nakhoda Sekam. (Maka) apabila sampai di Kuala Pahang dipersembahkan seperti titah Raja Kecik itu, maka tiadalah rela Sultan Abd al-Jalil /itu/. Maka lalu (lah) jadi berperang. Maka berperanglah Laksamana Nakhoda Sekam (itu melanggar) Kuala Pahang. Maka tiada beberapa hari maka Kuala Pahang pun alah (lah), akan tetapi/nya/ Sultan Abd al-Jalil (itu) tiada berani Laksamana // Nakhoda Sekam itu mengapa-ngapakan. Maka pergilah Laksamana Nakhoda Sekam itu mengadap Sultan Abd alJalil sembahnya, "Ampun tuanku, baiklah silakan ke Riau kerana pesan paduka anakanda silakan ayah ke Riau...Syahadan kata sahib al-hikayat di dalam hal antara itu datanglah pula seorang suruhan Raja Kecik, bernama si Emas | (Raden), membawa surat kepada Laksamana Nakhoda Sekam. ( Maka) tersebutlah di dalam surat itu, "Janganlah Sultan Abd al-Jalil dibawa ke Riau lagi, bunuhlah sekali, kita tahukan matinya //sahaja//.

(Hooker, Virginia Matheson, 1998: 65 - 66).

Tanpa penggunaan strategi diplomatik yang betul dan tidak wujud niat dalam sanubari seorang pemimpin untuk berhubung secara baik dengan kerajaan, maka ia bukan sahaja merencatkan hubungan diplomatik malahan menambahkan huru-hara antara Kerajaan Johor - Riau, dan Pahang. Hal ini demikian kerana akan adanya usaha untuk membalas semula perbuatan yang dilakukan oleh Raja Kecik terhadap Sultan Abd al-Jalil dan hal ini tidak akan berkesudahan sehingga matlamat untuk menjatuhkan Raja Kecik tercapai. Oleh hal yang demikian, cubaan untuk menjalinkan hubungan diplomatik antara kerajaan tersebut tidak wujud dalam buku nota masing-masing.

Antara cubaan waris keturunan Sultan Abd al-Jalil yang dikenal pasti dalam membalas semula tindakan Raja Kecik ialah:

a) Bekerjasama dengan opu-opu Raja Bugis untuk mengalahkan dan menamatkan kuasa autokratik Raja Kecik dalam kerajaan JohorRiau-Pahang (Hooker, Virginia Matheson, 1998: 67).

b) Memisahkan Tengku Kamariah dengan Raja Kecik. Tengku Kamariah merupakan anak kepada Sultan Abd al-Jalil dan isteri 
kepada Raja Kecik dan baginda sangat mencintai isterinya (Hooker, Virginia Matheson, 1998:64). Tujuan berbuat demikian adalah untuk melemahkan semangat Raja Kecik dan seterusnya menamatkan kuasa autokratiknya.

Matlamat untuk menjadi sebuah 'kerajaan autokratik' sememangnya tidak terdapat dalam prinsip hubungan diplomatik. Antara prinsip umum diplomatik itu mencintakan kedamaian dan persaudaraan, dan pertimbangan kesamarataan sedangkan istilah autokratik itu sendiri lebih menjurus kepada dominan kuasa. Kepelbagaian emosi negatif akan bercampur baur bagi mencapai hasrat untuk menakluki sesebuah kerajaan. Begitu jugalah yang telah dilakukan oleh Raja Kecik terhadap pemerintah Kerajaan JohorRiau-Lingga. Raja Kecik sanggup melakukan apa sahaja demi mencapai matlamatnya menjadi pemerintah tunggal kerajaan tersebut walaupun wujud unsur psikologi bagi melemahkan perancangannya. Misi menjadi kerajaan autokratik adalah amat penting baginya berbanding perkara lain, terutamnya dalam menjalinkan hubungan diplomatik.

\section{Perlanggaran Prinsip Etika dan Moral Hidup}

Perlanggaran prinsip etika dan moral hidup merupakan antara punca lain berlakunya kerencatan dalam sesuatu perhubungan diplomatik. Vishalache Balakrishnan (2009: 2) menyatakan bahawa dalam konteks pendidikan di Malaysia, etika dan moral digunakan sebagai terminologi yang sama walaupun ada sedikit perbezaan, di mana etika merujuk kepada peraturan dalam sesuatu situasi, manakala moral merujuk kepada perlakuan dan tingkah laku. Sementara itu, menurut Mimin Emi Suhaemi (2003: 39), etika dan moral ialah ilmu tentang kesusilaan yang mengatur bagaimana sepatutnya manusia hidup dalam masyarakat yang melibatkan aturan atau prinsip yang menentukan tingkah laku yang benar, iaitu baik atau buruk atau kewajipan dan tanggungjawab. Oleh itu, etika dan moral menuntut agar manusia sentiasa berpegang kepada peraturan tingkah laku yang positif dalam setiap keadaan yang berlaku.

Pemimpin dan pembesar yang berpegang kepada etika dan moral hidup akan sentiasa menjaga hubungan diplomatik yang dijalinkan. Namun, 
sekiranya kedua-dua golongan ini melakukan perkara yang sebaliknya, maka ia akan menyebabkan perpecahan kepada perpaduan yang dibina dan ketidakbolehpercayaan akan wujud untuk meneruskan hubungan tersebut. Antara perlanggaran prinsip moral dan etika yang dikenal pasti dalam naskhah historiografi kajian ialah menabur fitnah, khianat dan mendustakan atau memungkiri janji.

Menabur fitnah merupakan unsur negatif dalam kehidupan. Ia sangat bahaya dan mampu merosakkan sesebuah hubungan yang sedia terjalin (Saat Sulaiman, 2008:161). Fitnah juga merupakan provokasi berunsur perkataan yang menyebabkan tercetusnya perpecahan sebuah perpaduan yang dibina antara kerajaan. Ia sengaja dilakukan dengan mengadakan cerita atau memalsukan peristiwa serta menokok tambah keaiban dan kelemahan sesebuah kerajaan. Lazimnya, perbuatan ini didorong oleh sikap tamak, iri hati dan mementingkan diri sendiri. Selain itu, ia juga berlaku kerana keutamaan terhadap kedudukan dan keduniaan (harta benda) melebihi kepentingan agama dan hubungan sesama manusia. Implikasinya, sesebuah hubungan yang terjalin dengan baik dan jayanya sebelum ini akan berubah sekelip mata kepada permusuhan. Perlanggaran etika dan moral ini telah memaksa kerajaan yang terlibat bertindak untuk memutuskan hubungan tersebut. Berdasarkan situasi ini, Allah SWT telah berfirman, maksudnya, "Fitnah itu lebih besar (dosanya) daripada pembunuhan" (Surah al-Baqarah, ayat 217) dan,

\begin{abstract}
"Wahai orang yang beriman, jika datang kepada kamu seorang fasik membawa sesuatu berita, maka selidik (untuk menentukan) kebenarannya, supaya kamu tidak menimpakan sesuatu kaum dengan perkara tidak diingini, dengan sebab kejahilan kamu (mengenainya) sehingga menyebabkan kamu menyesali perkara yang kamu lakukan".
\end{abstract}

(Surah al-Hujurat: Ayat 6)

Dalam naskhah Tuhfat al-Nafis, diceritakan oleh pengarang bahawa hubungan diplomatik antara orang Melayu, Bugis dan Siak mengalami beberapa kali kegeruhan akibat daripada perbuatan fitnah. Ia berpunca daripada penyatuan dua bangsa yang telah menyebabkan Johor dan Riau serta jajahan takluknya menjadi kuat. Sebahagian masyarakat tempatan 
melihat bahawa hubungan tersebut boleh memberi kesan negatif kepada keturunan Sultan Johor pada masa akan datang dan juga wujud perasaan bimbang terhadap pentadbiran dan pemerintahan orang Melayu yang akan dikuasai oleh bangsa Bugis.

Oleh hal yang demikian, salah satu cara untuk memutuskan hubungan tersebut, iaitu dengan melakukan gangguan dalam hubungan tersebut. Jalan terbaik ialah dengan menabur fitnah. Lihat permulaan rentetan peristiwa di bawah ini:

a) Wujud perasaan iri hati.

...Demikian lagi (Baginda) Sultan Sulaiman balik dari/pada/ melanggar Siantan itu, sangatlah rapatnya dengan suku-suku pihak Bugis, serta tampak kasih sayangnya tulus ikhlasnya dan mesranya (paduka anakanda baginda) Yang Dipertuan Muda adik-beradik. Syahadan apabila dilihat oleh setengah (suku-suku sebelah) Melayu hal yang demikian itu, maka terbakarlah hatinya $f$ hasad dan hakid yang tertanam di dalam hatinya memakan/lah/ apinya itu kepada akalnya itu, jadilah mengikut akan hawa nafsunya, yang tiada hiraukan manfaat dan muzarat fi al-dunia wa al-akhirat, intiha).

(Hooker, Virginia Matheson, 1998: 139).

b) Pelbagai cubaan untuk menabur fitnah- penggerak utama ialah Raja Terengganu (menantu Sultan Sulaiman).

Maka (adalah suku-suku Melayu serta) Raja Terengganu gaduhlah tiap-tiap malam (berjaga katanya, "Bugis-bugis ini hendak khianat." Maka tiap-tiap malam berbuatlah gaduh mengatakan segala BugisBugis hendak membakar rumah, dan hendak mengamuk). Maka di dalam sebulan dua tiga kali datang fitnah... Kemudian selang (empat) lima (hari) gaduh pula orang Terengganu, dan suku Melayu itu, mengatakan Bugis hendak membakar kota (sudah) dikejarnya lari...

(Kemudian renggang dua tiga hari datang pula fitnah, mengatakan Bugis-Bugis hendak jahat, memakai baju rantai, berendak Bintan, berkeris bercabut, berjalan di darat kota. Maka berkeliaran pula seorang orang-orang Terengganu dengan lembing beberkas-berkas 
mengejar ke darat, dan mengepung. /Maka/ riuh rendah berjeritan terlari-lari dengan lembing, beberapa berkeris.

(Hooker, Virginia Matheson, 1998: 139 - 140)

Akhirnya, Sultan Sulaiman mendapat tahu fitnah tersebut sengaja direka oleh menantunya. Baginda berdukacita dengan tindakan menantunya yang telah membuat onar di negeri tersebut dengan tujuan untuk memutuskan hubungan diplomatik bangsa Melayu dengan Bugis. Hasilnya, baginda telah membiarkan bangsa Bugis menghukum Raja Terengganu (menantunya) demi menjaga hubungan tersebut. Dalam hal ini, walaupun Sultan Sulaiman sanggup mengetepikan ikatan kekeluargaannya demi menstabilkan hubungan kedua bangsa tersebut. Secara tersiratnya, hubungan kedua-dua bangsa ini ibarat 'telur di hujung tanduk.' Hal ini demikian kerana selepas peristiwa tersebut, banyak lagi kejadian yang melibatkan fitnah untuk mengeruhkan hubungan kedua-dua pihak ini.

Seterusnya, dalam naskhah historiografi Melayu, acapkali perbuatan khianat diketengahkan oleh pengarang sebagai sebuah nilai negatif dalam sesebuah masyarakat. Tujuannya hanyalah satu, iaitu memberikan pengajaran kepada pembaca tentang kesan di sebalik perbuatan tersebut. Sebagai contoh, dalam naskhah Sulalat al-Salatin, diceritakan bahawa setelah Melaka diserang dan ditakluki oleh Portugis, Raja Abdullah, iaitu Raja Kampar, iaitu saudara kepada Sultan Mahmud Syah bercadang untuk menjalinkan hubungan baik dengan pihak Portugis. Dengan harapan, Portugis dapat menyerahkan semula Melaka dan tanah jajahan Melaka kepada baginda. Raja Abdullah tidak ingin melihat Melaka di bawah pengaruh penjajah dan baginda sanggup memikul tanggungjawab mentadbir Melaka dan jajahan Melaka demi mempertahankan kedaulatan dan maruah Melayu.

Maka Raja Abdullah bertitah pada segala pegawai, “Apa bicara Orang Kaya-kaya segala pegawai Kampar, kita hendak mendapatkan jaga-jaga Peringgi yang di Selat Unggaran itu, kita hendak muafakat dengan kapitannya, mudah-mudahan dikembalikannya segala jajahan Melaka kepada kita, kerana yang empunya waris kerajaan Melaka itu kita."

(A. Samad Ahmad, 2010: 275) 
Untuk menunjukkan kesungguhan baginda mendapatkan semula Melaka, Raja Abdullah telah berangkat ke Selat Ungaran. Setelah sampai di tempat tersebut, baginda telah menghantar seorang hambanya untuk memaklumkan kedatangan dan hajat baginda untuk berjumpa dengan Kapitan Mor. Sebaik sahaja mengetahui niat Raja Abdullah ingin berbaikbaik dengan pihak Portugis, Kapitan Mor bersetuju untuk berjumpa dengan Raja Abdullah. Namun, perjumpaan tersebut diiringi dengan syarat, iaitu pihak Raja Abdullah hanya dibenarkan menggunakan sebuah sampan sahaja. Sekiranya lebih daripada satu, Portugis akan membedil sampan Raja Abdullah dan berpendapat bahawa Raja Abdullah hanya bermain kata dan tidak bersungguh menjalinkan hubungan tersebut. Raja Abdullah bersetuju dengan syarat tersebut. Bagi baginda, peluang mendapatkan semula Melaka kelihatan cerah, memandangkan pihak Portugis memberikan 'lampu hijau' untuk berjumpa dengan baginda. Contohnya:

... Maka hamba Raja Kampar itu pun dekatlah, lalu naik ke fusta Peringgi itu. Maka segala kata Raja Abdullah itu semuanya dikatakannya kepada kapitan Peringgi itu. Maka kata kapitan itu, "Jika sungguh Raja Kampar mau bersahabat dengan Kapitan Mor Melaka, banyak boleh untung; kembalilah pakanira bahawa Raja Kampar ke mari berkata-kata dengan kita; jangan banyak datang, satu sampan ini juga; jika banyak kita bedil, tidak sungguh Raja Kampar mau bersahabat dengan Kapitan Mor."

(A. Samad Ahmad, 2010: 276)

Kegembiraan sementara baginda itu menggambarkan bahawa tidak ada sekelumit pun dalam hati baginda rasa benci dan dendam kepada Portugis yang telah menjajah kerajaan saudara baginda. Malahan, Raja Abdullah lebih bersikap terbuka dengan mempercayai kata yang diucapkan oleh Kapitan Mor itu tanpa rasa was-was. Walaupun keberangkatan baginda menuju ke kapal Peringgi itu ditegah oleh pembesar baginda kerana dibimbangi ada niat yang tersembunyi di sebalik permintaan tersebut, Raja Abdullah tetap berkeras untuk pergi. Baginda pun bertolak tanpa pengawal istana dengan menaiki sebuah sampan dan hanya ditemani oleh dua orang hambanya yang membawa sirih untuk hadiah pembuka bicara. Raja Abdullah yakin bahawa niatnya adalah betul, iaitu untuk mempertahan dan menyelamatkan kedaulatan Melaka serta waris keturunannya. 
...maka kata kapitan fusta, "Apa mau raja hendak bertemu dengan kita?" Maka sahut Raja Abdullah, "Kita mau berkasih-kasihan dengan Kapitan Mor; akan segala jajahan Melaka mau kita pinta pada Kapitan Mor.” Maka sahut kapitan fusta itu, "Lebih lagi suka Kapitan Mor mau memberi segala anak negeri Melaka pada raja, akan jadi pengapit pada raja Portugal."

\section{(A. Samad Ahmad, 2010: 276 - 77)}

Semasa perbincangan itu, baginda tidak menyedari bahawa baginda telah dikhianati. Pihak Portugis dengan gerakan perlahan-lahan membongkar sauh, menarik layar dan terus belayar. Raja Abdullah ditangkap dan dijadikan tawanan mereka (A. Samad Ahmad, 2010: 277). Menurut pengarang Sulalat al-Salatin, Raja Abdullah telah dihantar ke Goa dan tidak diketahui nasib baginda selepas itu. Oleh hal yang demikian, berakhirlah sudah perbincangan diplomatik yang penuh dengan muslihat dan khianat oleh pihak Portugis terhadap Kerajaan Kampar. Bak kata pepatah 'susu diberi, dibalas dengan tuba.' Pengajaran dalam peristiwa ini ialah jangan mudah mempercayai kata-kata penjajah yang telah mengkhianat kedaulatan sesebuah negara.

Satu lagi peristiwa tentang perbuatan khianat ini telah dibincangkan oleh pengarang Hikayat Aceh. Permusuhan antara kerajaan pimpinan Sultan Muzaffar Syah daripada Aceh dan kerajaan pimpinan Raja 'Inayat Syah daripada Dar al-Kamal telah berlanjutan selama beberapa tahun dan kedua kerajaan ini pun telah banyak kali terlibat dalam peperangan (Teuku Iskandar, 2001: 9 - 10). Apabila melihat keadaan sedemikian, agak sukar untuk mengatakan bahawa kedua kerajaan ini bersetuju untuk berdamai dengan menjalinkan hubungan diplomatik.

Sudah menjadi kelaziman, peperangan berlaku disebabkan sesebuah negara itu ingin menakluki kerajaan lain. Memandangkan Sultan Muzaffar Syah (Aceh) tidak pernah berjaya menguasai kerajaan pimpinan Raja 'Inayat Syah, maka baginda mula mencari ikhtiar dengan mengalihkan pendekatan daripada kekerasan kepada unsur diplomasi. Namun dalam masa yang sama, baginda ingin berbuat khianat terhadap kerajaan Raja 'Inayat Syah. Dalam hal ini, niat dan pelaksanaan diplomatik itu tidak 
berlaku seiring. Hal ini disebabkan, niat Sultan Muzaffar Syah itu baik, iaitu ingin berdiplomasi, namun cara pelaksanaannya dengan mengkhianat; Raja I'nayat Syah merupakan perbuataan yang negatif dan tidak patut dicontohi. Dalam ketamakannya ingin menguasai kerajaan Raja 'Inayat Syah, baginda sanggup membelakangkan nilai moral. Kelakuan yang bermoral ialah tingkah laku yang sejajar dengan tatasusila atau peraturan masyarakat yang merangkumi nilai murni seperti benar, belas kasihan, hati suci, cintakan kedamaian, hormat-menghormati, bekerjasama, sederhana, mengenang budi, dan bersemangat kemasyarakatan (Hashim Musa, 2001: 57).

Antara gerak laku untuk menjayakan perbuatan khianat Sultan Muzaffar Syah yang dikenal pasti ialah:

a) Menghantar utusan peminangan

Menghantar utusan merupakan salah satu ciri diplomatik Melayu. Sultan Muzaffar Syah menghantar utusan untuk meminang tuan puteri Raja I'nayat Syah yang bernama Setia Indera. Hal ini disebabkan, hanya melalui ikatan perkahwinan akan dapat mengeratkan hubungan antara kerajaan.

...Maka ia menyuruhkan antusannya kepada Raja 'Inayat Syah yang di Dar al-Kamal itu mengatakan dirinya menelangkai anak Raja 'Inayat Syah yang bernama Setia Indera. Maka Raja 'Inayat Syah pun menengarkan kata yang lemah lembut kabul berbesan dengan Raja Muzaffar Syah.

(Teuku Iskandar, 2001: 10)

b) Memberi hadiah

Sultan Muzaffar Syah memberikan hadiah untuk menyakinkan Raja I'nayat Syah bahawa niatnya berkahwin dengan Tuan Puteri Setia Indera adalah suci dan ikhlas berbesan dengan Raja 'Inayat Syah. Hal ini telah berjaya mencipta kepercayaan di pihak Raja I'nayat Syah. Setelah berapa kali datang antusan Raja Muzaffar Syah memba(wa) hadiah daripada mata benda yang mulia-mulia akan Raja 'Inayat Syah $\mid$ menerima hadiah daripadanya itu, maka ia pun terlalu sukacita kerana pada sangkanya tadapat tiadalah sampai seperti yang dikehendakinya itu.

(Teuku Iskandar, 2001: 10) 
c) Meminta keizinan melakukan perarakan

Apabila melihat kesungguhan Raja Muzaffar Syah berbesan dengan baginda, maka Sultan 'Inayat Syah mengabulkan permintaan Raja Muzaffar Syah. Perarakan dilakukan bertujuan untuk menyatakan kegembiraan kepada masyarakat sekitar kerana kedua buah kerajaan yang bermusuhan selama ini akan hidup berdamai.

Maka pada suatu ketika disuruhkan Raja Muzaffar Syah antusan kepada Raja 'Inayat Syah mengatakan bahawa ia hendak mengarak daf'a dan segala hadi(ah) yang indah-indah seperti 'adat raja-raja berbesan samanya raja-raja.

(Teuku Iskandar, 2001: 10)

Kesan daripada ketiga-tiga gerak laku yang dirancang oleh Raja Muzaffar Syah, baginda telah berjaya menarik perhatian Raja 'Inayat Syah. Dengan berorientasikan kepada perancangan idea untuk mengurus dan mampu melahirkan kepercayaan melalui manipulasi secara terancang dan kreatif telah dapat mempengaruhi persepsi Sultan 'Inayat Syah terhadap kerajaan pimpinan Raja Muzaffar Syah. Lihat contoh petikan di bawah:

Maka Raja 'Inayat Syah pun tiadalah behena belenggara akan isti' adat peperangan seperti 'adat yang dahulu kala. Pada sangkanya [sangkanya]: 'Bahawa yang seteru kita jadilah saudara pada kita.' Tiada ia akan tahu akan tipu Raja Muzaffar Syah akan dia itu.

(Teuku Iskandar, 2001: 10)

Setelah itu, Raja Muzaffar Syah pun membuat persediaan dengan memasukkan semua peralatan senjata ke dalam geta keemasan untuk dibawa bersama semasa perarakan baginda menuju ke istana Raja 'Inayat Syah. Perarakan diraja itu disambut mesra oleh hulubalang dan pembesar kerajaan pimpinan Raja 'Inayat Syah serta mengiringi dan mengarak bersama-sama dengan rakyat Raja Muzaffar Syah tanpa rasa curiga. Sebaik sahaja sampai di perkarangan istana Raja 'Inayat Syah, Raja Muzaffar Syah dan hulubalangnya mengeluarkan senjata dalam simpanan baginda, lalu membunuh hulubalang tersebut. 
Kejadian tersebut telah mengejutkan Raja 'Inayat Syah. Baginda sama sekali tidak menyangka tindakan Raja Muzaffar Syah yang sanggup mengkhianati baginda dengan berpura-pura ingin menjalinkan hubungan diplomatik dengan baginda. Akhirnya, tanpa persiapan rapi, Raja 'Inayat Syah dan kerajaan baginda berjaya ditakluki oleh Raja Muzaffar Syah dan hal ini telah merencatkan hubungan diplomatik antara dua buah negara.

Kata yang berceritera: Maka | demikian segala hulubalang dan segala ra'yat Dar al-Kamal bertimbun umpama suatu bukit dan darah mereka itu mengalir seperti anak sungai. Maka negeri Dar al-Kamal pun alah pada ketika itu dan Raja 'Inayat Syah pun ta'luklah pada Raja Muzaffar Syah. Maka segala arta segala kelengkapan Raja 'Inayat Syah ...

(Teuku Iskandar, 2001: 11)

Hubungan diplomatik juga dapat berjalan lancar berdasarkan perjanjian yang dipersetujui antara kerajaan yang terlibat. Perjanjian ialah komitmen manusia untuk terus berhubungan dan dapat mengawal sesebuah kerajaan daripada berbuat sesuka hati. Melalui dapatan yang diperoleh, perjanjian digunakan untuk mengelakkan sesebuah negara daripada ditakluki dan membuat keputusan bersama untuk menjalinkan hubungan diplomatik. Sekiranya sesebuah kerajaan memungkiri perjanjian yang telah dipersetujui, ia bukan sahaja merencatkan hubungan, malahan menggambarkan keperibadian atau ciri masyarakat dalam kerajaan berkenaan. Apabila perjanjian dilanggar, maka banyak perkara yang tidak diingini akan berlaku seperti peperangan, penaklukan dan pembunuhan.

Apabila meneliti naskhah Tuhfat al-Nafis, acapkali akan menemui peperangan dan pertelingkahan antara Raja Kecik dari Siak, Sultan Sulaiman, opu-opu Raja Bugis, dan raja lain. Menurut Raja Ali Haji, hampir sepuluh kali peperangan yang melibatkan pihak ini berlaku dalam Tuhfat al-Nafis (Hooker, Virginia Matheson, 1998: 193 - 196). Namun, terdapat juga pihak yang ingin menyelesaikan permusuhan ini, antaranya ialah Sultan Khalifatullah Muhammad Syah. Baginda telah membuat surat perjanjian persetiaan antara raja Pagar Ruyung, Johor, dan Minangkabau. Antara isi perjanjian persetiaan tersebut ialah: 
“...Barang siapa anak Minangkabau yang di dalam perintahan Johor hendaklah mengikut perintahan Johor. Barang siapa tiada mengikut, dimakan (sumpah) besi kawi tiada selamat kepada anak cucu (cicitnya), (tiap-tiap suatu pekerjaannya yang dicitanya dikutuki Allah Ta'ala." Demikianlah bunyinya sumpah setianya itu.

(Hooker, Virginia Matheson, 1998: 88 - 89)

Perjanjian tersebut telah diakui oleh ketiga-tiga pihak dan bersetuju untuk menjalinkan hubungan diplomatik dan hidup berdamai tanpa perang. Tiga kelompok bangsa ini telah bersumpah setia di dalam masjid untuk mengesahkan bahawa tiada pihak yang akan memungkiri perjanjian yang telah dibuat. Kesan daripada perjanjian tersebut, Raja Kecik telah bersetuju memulangkan rakyat Johor yang dijadikan tawanan baginda dan juga mengembalikan teluk rantau Johor kepada Sultan Sulaiman dan Yang Dipertua Muda Riau. Sebagai balasan, Sultan Sulaiman bersetuju untuk mengabulkan hajat Raja Kecik untuk membawa isterinya, iaitu Tengku Kamariah yang berada di Johor pada masa itu untuk kembali bersamanya pulang ke Siak.

Namun, Raja Kecik bersikap hipokrit dengan berpura-pura bersetuju dan mengakui perjanjian tersebut. Setelah maksudnya tercapai dengan membawa pulang semula isterinya, Raja Kecik telah mempersiapkan angkatan tentera untuk melanggar Riau semula. Keadaan ini telah merencatkan hubungan diplomatik yang telah dipersetujui oleh ketiga-tiga pihak sebelum ini. Raja Kecik tanpa sedikit rasa penyesalan telah berkubu di Pulau Bayan dan menyerang Riau. Akhirnya, akibat memungkiri janji, ramai angkatan Raja Kecik yang terbunuh oleh angkatan tentera opu-opu Raja Bugis dan memaksa Raja Kecik berundur daripada Riau dan kembali ke Siak.

Selain peristiwa di atas, diceritakan oleh pengarang naskhah Tuhfat al-Nafis bahawa Raja Kedah telah berjanji kepada opu-opu Raja Bugis untuk memberikan hadiah sebanyak 15 bahara wang emas sekiranya berjaya mengalahkan adinda baginda yang telah merampas takhta baginda (Hooker, Virginia Matheson, 1998:83). Setelah baginda mendapat semula takhtanya, baginda hanya membayar tiga bahara wang emas dan berjanji 
akan membayar selebihnya pada masa akan datang dan opu-opu Raja Bugis pun bersetuju dengan perjanjian tersebut. Namun sehingga baginda mangkat dan opu-opu Raja Bugis meninggal dunia, baki wang emas tersebut masih belum dilaksanakan.

Oleh itu, Raja Haji Engku Kelana Pangeran Suta Wijaya dari negeri Inderagiri telah berjumpa dengan Sultan Salihuddin, iaitu Yang Dipertuan Selangor untuk menceritakan peristiwa tersebut. Raja Haji dengan rela hati dan bersedia memikul tanggungjawab untuk menjadi wakil bagi bangsa Bugis bagi mendapatkan semula baki wang emas itu. Lalu, keduanya sepakat berjumpa dengan anakanda Sultan Kedah yang telah menaiki takhta pada ketika itu untuk menyampaikan hajat mereka. Buktinya seperti petikan ini:

\begin{abstract}
"Patik waki'nya menuntut perjanjian itu menjadi perang sebab (kerana janjinya, kerana) Kedah sudah makmur kerana perjanjian opu-opu dahulu. Apabila makmur negeri Kedah adalah belanjabelanja opu-opu melanggar Kedah dahulu itu patutlah hendak diganti. Serta ada pula perjanjian lain daripada itu, iaitu (lima) belas bahara wang. Maka sudah dibayar tiga bahara tinggal lagi dua belas bahara, sudah berpuluh tahun belum juga raja Kedah menyempurnakan perjanjiannya itu, dan surat-suratnya pun ada baik (lah) kita tunjukkan kepada raja Kedah itu." Maka jawab Yang Dipertuan Selangor, "Jikalau begitu, baik(lah) kita pergi sendiri." Maka jawab Kelana (Pangeran Suta Wijaya Raja Haji, "Baiklah."
\end{abstract}

(Hooker, Virginia Matheson, 1998: 213)

Apabila mendengar Raja Haji dalam perjalanan menuju ke Kedah, Sultan Kedah mengarahkan rakyatnya supaya bersiap sedia khususnya dalam aspek pertahanan dan ketahanan untuk menghadapi kedatangan rombongan Raja Haji. Sebaik sahaja sampai di Kedah, Raja Haji berasa hairan dengan tindakan Sultan Kedah yang menyambutnya seperti menyambut pihak lawan lakunya. Hal ini disebabkan baginda datang hanya ingin menuntut janji antara almarhum ayahanda Sultan Kedah dengan opu-opu Raja Bugis dan bukannya untuk berperang. Namun, situasi yang digambarkan oleh pengarang memperlihatkan bahawa Sultan Kedah itu sedang bersiap untuk berperang dengan rombongan Raja Haji. 
Namun, Raja Haji tetap meneruskan niatnya dengan menghantar suliwatang untuk menemui Sultan Kedah dan menyampaikan tuntutan janji tersebut. Setelah Sultan Kedah mendengar hajat Raja Haji itu, baginda menolak dan mengkehendaki kedua-dua pihak meluputkan janji tersebut. Hal ini demikian kerana orang yang membuat janji tersebut ialah almarhum ayahanda baginda dan bukannya baginda. Oleh itu, baginda tidak ada kenamengena dengan perjanjian tersebut dan enggan bertanggungjawab serta tidak akan mengotakan hajat Raja Haji walau apapun yang terjadi.

Setelah (sudah) habis dibacanya titahnya kepada suliwatang, "Ini surat perjanjian orang tua-tua dahulu dan yang berjanji dan yang menerima (per)janji(an) tiada lagi. Dan yang saya menjadi raja ini bukannya Bugis mengangkat saya menjadi raja. (Dan) saya kirim salam (takzim) saja kepada Raja Haji, janganlah dipanjangkan lagi perkara (nya) ini, (antara kita sudah seperti menjadi | sanak saudara. Baliklah suliwatang, tiadalah kita memberi surat lagi, kerana suliwatang yang datang ini memadailah."

(Hooker, Virginia Matheson, 1998: 215)

Keangkuhan dan ketidaksopanan Sultan Kedah itu telah menimbulkan kemarahan di pihak Raja Haji. Raja Haji merasa maruah bangsanya tercabar dan perjanjian antara bangsa Melayu Kedah dan Bugis yang membentuk hubungan diplomatik dahulu telah diperlekehkan begitu sahaja oleh waris kesultanan Kedah itu. Raja Haji kecewa melihat keadaan sedemikian kerana pengorbanan nyawa oleh opu-opu Raja Bugis dibalas dengan penghinaan. Lalu, timbul rasa di hati untuk memerangi Kerajaan Kedah.

Akhirnya, hubungan diplomatik yang terbina terencat begitu sahaja disebabkan sikap Sultan Kedah yang enggan memenuhi janji dan lebih mempertahankan egonya sebagai sebuah kerajaan yang kukuh dan menganggap tanpa bantuan Bugis, selama ini Kedah mampu hidup berdikari dan hidup dengan senang-lenang. Sementara itu, bangsa Bugis yang diwakili oleh Raja Haji berasa sangat malu dengan penolakan janji dan penghinaan Sultan Kedah terhadap bangsa Bugis serta berpendapat tanpa bantuan opu-opu Raja Bugis pada waktu dahulu, Kedah tidak akan berada di tahap kegemilangannya seperti sekarang ini. Apabila dasar persefahaman, toleransi serta cintakan keamanan tidak wujud lagi dalam hati di sebelah 
pihak, maka akan terjadi peperangan, penaklukan dan pembunuhan. Dalam kisah di atas, Sultan Kedah yang memungkiri janji telah menerima padahnya apabila baginda terpaksa berundur daripada Kedah kerana tidak dapat bertahan daripada serangan angkatan tentera Raja Haji.

\section{KESIMPULAN}

Hubungan diplomatik yang terbentuk sememangnya membawa impak positif kepada kerajaan yang terlibat. Perkembangan dan pertumbuhan dalam aspek ekonomi, percampuran budaya dan sosial merupakan antara kebaikan yang dapat dilihat dengan jelas. Segala kelompangan dalam urusan pentadbiran dipenuhi dengan kerjasama antara kerajaan. Namun, sesebuah hubungan diplomatik tidak dapat bertahan lama apabila wujudnya unsur-unsur negatif dalam hubungan tersebut. Dalam perbincangan ini, terdapat beberapa faktor penyebab tercetusnya kerencatan sesebuah hubungan diplomatik, terutamanya dalam Kerajaan Melaka, Johor dan Aceh. Faktor kerencatan yang ketara dalam Kerajaan Melaka yang dikisahkan dalam Sulalat alSalatin, Kerajaan Johor Riau Lingga dalam Tuhfat al-Nafis dan Kerajaan Aceh dalam Hikayat Aceh lebih menjurus kepada faktor wujudnya interaksi sosial berbeza antara kerajaan serta perlanggaran prinsip etika dan moral hidup. Namun, wujud sedikit perbezaan dalam Tuhfat al-Nafis apabila karya ini mengetengahkan satu lagi faktor kerencatan hubungan diplomatik yang berlaku dalam Kerajaan Johor-Riau-Lingga berbanding kedua-dua kerajaan, iaitu matlamat untuk menjadi 'kerajaan autokratik.' Faktor-faktor kerencatan ini telah membawa kepada berlakunya peperangan, pengkhianatan dan pembunuhan. Secara terang-terangan, pemerintah kerajaan tersebut lebih berfokuskan kepada penebaran kuasa dan pengaruh semata berbanding mempertahankan nilai toleransi, kerjasama dan memantapkan keamanan antara kerajaan yang mempunyai hubungan diplomatik. 


\section{RUJUKAN}

A. Samad Ahmad (Penyl.). (2010). Sulalatus Salatin: Sejarah Melayu (Edisi kesepuluh). Kuala Lumpur: Dewan Bahasa dan Pustaka.

AbdulHamīd A. AbūSulaymān. (1987). Towards an Islamic theory of international relations: New directors for methodology and thought. Herndon, VA: International Institute of Islamic Thought.

Abdullah Hassan \& Ainon Mohd. (2007). Teori \& teknik kepimpinan: Panduan aplikasi di tempat kerja. Kuala Lumpur: PTS Professional.

Akashah Ismail. (2010). Sejarah. Kuala Lumpur: Pelangi Publishing Group Bhd.

Alo Liliweri. (2005). Prasangka dan konflik: Komunikasi lintas budaya masyarakat multikultur. Yogyakarta: LKIS.

Arshad Md. Gaus. (2005). Siri motivasi dan kecemerlangan utusan: Magnet diri. Kuala Lumpur: Utusan Publications \& Distributors Sdn. Bhd.

Cartesao, A. (ed.). (1944). The Suma Oriental of Tome Pires (Jilid Dua). London: The Hakluyt Society.

Chamil Wariya. (1989). Pergolakan antarabangsa: Perkembangan dan isu utama sejak 1945. Kuala Lumpur: AMK Interaksi Sdn. Bhd.

Choudhury, G.W. (1993). The Prophet Muhammad his life and eternal message. Kuala Lumpur: WHS Publications Sdn. Bhd.

Deni Prasetyo. (2009). Mengenal kerajaan-kerajaan Melayu Nusantara. Yogyakarta: Pustaka Widyatama.

Ensiklopedia Dunia. (2005). Kuala Lumpur: Dewan Bahasa dan Pustaka.

Fadhulullah Jamil. (1984). Perhubungan antara Kerajaan Aceh dengan Semenanjung Tanah Melayu. Satu tinjauan sejarah di sekitar abad ke-16 hingga abad ke-17 Masihi. Nusantara, Vol. 12, 37 - 58.

H. A. Fuad Said. (2002). Ketatanegaraan menurut Syari 'at Islam. Kuala Lumpur: Dewan Bahasa dan Pustaka.

Hall, D. G. E. (1966). A history of South-East Asia. London: Macmillan Publishers. Hashim Musa. (2001). Falsafah, logik, teori nilai dan etika Melayu: Suatu pengenalan. Kuala Lumpur: Akademi Pengajian Melayu.

Hashim Musa. (2004). Pemerkasaan Tamadun Melayu Malaysia: Menghadapi globalisasi Barat. Kuala Lumpur: Penerbit Universiti Malaya \& Pusat Dialog Peradaban.

Holsti, K. J. (1983). International politics: A framework for analysis. New Jersey: Prentice-Hall, Inc.

Hooker, Virgina Matheson. (Penyl.). (1998). Tuhfat al-Nafis. Kuala Lumpur: Yayasan Karyawan \& Dewan Bahasa dan Pustaka.

Joshua S. Goldstein. (1994). International relations. New York: HarperCollins.

Maryati \& Suryawati. (2003). Sosiologi I. Jakarta: Erlangga.

Mimin Emi Suhaemi. (2003). Etika keperawatan: Aplikasi pada praktik. Jakarta: EGC. 
Mohd Jamil Mukmin. (2011). Sejarah hubungan diplomasi Kerajaan Melayu: Satu tinjauan. Jurnal IKSEP, Vol. 2, 71 - 90.

Mokhtar Muhammad. (2005). Perhubungan antarabangsa: Konsep dan konteks. Kuala Lumpur: Anzagain Sdn. Bhd.

Muhammad Afifi Abdul Razak \& Azman Md Zain. (2003). Hubungan antarabangsa dan dunia Islam. Jurnal YADIM, Vol. 5, 46 - 71.

Murdiyatmoko \& Handayani. (2004). Sosiologi I. Jakarta: Grafindao Media Pratama.

Saat Sulaiman. (2008). Anak adalah anugerah. Kuala Lumpur: Utusan Publications \& Distributors Sdn. Bhd.

Salmah Jan Noor Muhammad. (2013). Ilmu diplomatik Melayu dalam Kesusasteraan Melayu. Tesis Ijazah Doktor Falsafah. Fakulti Bahasa Moden dan Komunikasi, Universiti Putra Malaysia. Serdang.

Teuku Iskandar Teuku Ali Basyah (Penyl.). (2001). Hikayat Aceh. Kuala Lumpur: Yayasan Karyawan.

Tim Mitra Guru. (2006). Ilmu pengetahuan sosial sosiologi. Jakarta: Erlangga.

Vishalache Balakrishnan. (2009). Pendidikan Moral untuk universiti dan kolej. Shah Alam: Arah Pendidikan Sdn. Bhd.

Yusoff Iskandar \& Abdul Rahman Kaeh. (1978). Sejarah Melayu: Satu pembicaraan kritis dari pelbagai bidang. Kuala Lumpur: Heinemann Educational Books (Asia) Ltd. 